Biol. Neonat. 1961;3:I-IV

\title{
Contents, Vol. 3, 1961
}

\section{INDEX}

Árvay, A.; Nagy, T. et Baszó, J.: L’importance des excitations cumulatives neurotropes dans la genèse des malformations congénitales. - The Importance of Neurotropic Overload Stimuli in the Genesis of Congenital Malformations. - Die Bedeutung kumulierender neurotroper Stimuli für die Genese angeborener Mißbildungen 1

Auricchio, S.; Rigillo, N. and Di Toro, R.: The Biosynthesis of Nicotinic Acid from Tryptophan in the Rat Liver during Pregnancy and Foetal and Neonatal Life. - Bíosynthèse de Vacíde nicotíníque à partir du triptophane dans lefoie du rat, pendant la gestation et les périodes fcetales et néonatales. - Die Biosynthese der Nikotinsäure aus Tryptophan in der Rattenleber während der Gestation und der Foetal- und Neonatalperiode $\quad 149$ Baszó, J.: vide Árvay, A.

Baudey, J.: vide Larroche, J.C.

Benirschke, K.: vide Takeuchi, A.

Bernhard, W. G.: vide Gordon, H.W.

BrücK, K.: Temperature Regulation in the Newborn Infant. - Regulation thermique chez le nouveau-né. - Die Entwicklung der Temperaturregelung beim Menschen 65 Cara, J.: vide Stave, U.

Chanez-Bel, C.; Swierczewski, E. et Minkowski, A.: Le magnesium dans le sang de la veine ombilicale. (Comparaison avec le sang maternel durant la gestation.) - Magnesium in the Blood from Umbilical Vein. (Comparison with Magnesium in the Maternal Blood during Gestation.) - Der Magnesiumgehalt des Nabelvenenblutes. (Verglichen mit dem Magnesiumgehalt des mütterlichen Blutes während der Schwangerschaft.) 311

Cohlan, S. Q. and Stone, Sh.M. : Observations on the Effect of Experimental Endocrine Procedures on the Teratogenic Action of Hypervitaminosis A in the Rat. - Observations sur les ejfets de procédés endocrinologiques expérímentaux sur Vaction tératogène de $\Gamma$ hypervitaminose A du rat. - Beobachtungen über die Wirkung von experimentellen endokrinen Maßnahmen auf den teratogenen Einfluß der A-Hypervitaminose bei der Ratte .... 330 Colin, J.: vide Paupe, J.

Coronini, C.; Flamm, H. und Kovac, W.: Eine weitere Virusinfektion der fetalen menschlichen Lunge. - Another Virus Infection of the Fetal Human Lung. - Une nouvelle infection virale du poumon foetal humain 24

Di Toro, R.: vide Auricchio, S.

Flamm, H.: vide Coronini, C.

Gibelin, C: vide Swierczewski, E.

Gordon, H. W.; Peer, L. A. and Bernhard, W. G.: The Relation of the Teratogenic Action of Cortisone to Liver Transaminase Activity. - Relation entre Cactívité tératogène de la cortisone et Tactívíté transaminase du foíe. - Die Beziehung der teratogenen Wirkung von Cortison zur Leber-Transaminaseaktivität 36 Hänninen, P.: vide Salmi, T. 
Jäykkä, S.: The Problem of the Dormant Fetal Organs: The Kidneys, Lungs and the Gut. - Le problème des organes fcetaux «en sommeíl physíologíque»: les reins, les poumons et Гíntestín. Das Problem der ruhenden Fòtalorgane: Nieren, Lungen und Darm .... 343

Kaplan, B.: vide Stern, L.

Koch, P. and Schwick, G.: The Activity of Platelet Factors 1-4 in Umbilical Vein Blood. Uactívité des facteurs plaquettaires 1-4 dans le sang de la veíne ombílícale. - Uber die Aktivität der Thrombocytenfaktoren 1-4 im Nabelvenenblut $\quad 302$

Kovac, W.: vide Coronini, C.

Larroche, J.C. et Baudey, J.: Cavum septi lucidi, cavum Vergae, cavum veli interpositi: Cavités de la ligne médiane. Etude anatomique et pneumoencéphalographique dans la période néo-natale. - Cavum septi pellucidí, Cavum Vergae, Cavum veli interpositi: Cavities of the Median Line. Anatomical and Pneumoencephalographíc Study in the Neonatal Period. - Cavum septi pellucidi, Cavum Vergae, Cavum veli interpositi: Höhlen der Medianlinie. Anatomische und pneumoencephalographische Untersuchungen in der Neugeborenenperiode193

Lelong, M.: vide Paupe, J.

Lind, J.: vide Stern, L.

Minkowski, A.: vide Chanez-Bel, C.

Minkowski, A.: vide Swierczewski, E.

Nagy, T.: vide Árvay, A,

Paupe, J.; Colin, J.; Politis, E. et Lelong, M.: Variations physiologiques de la calcémie chez la mere au moment de Taccouchement dans le cordon et chez le nouveau-né. - Some Physiological Variations of Blood Calcium Level in Mothers during Labour, in Cord and in Newborn Infants. - Physiologische Variationen der Serumcalciumwerte bei der Mutter im Moment der Geburt, in der Nabelschnur und beim Neugeborenen 357

Peer, L.A.: vide Gordon, H.W.

Peltonen, T.: vide Salmi, T.

Politis, E.: vide Paupe, J.

Rickenbacher, J. und Töndury, G.: Erkrankt der Fetus bei Grippe in graviditate ? -

Is the Foetus Involved in Case of Influenza of the Mother during Gr avidity ? - La grippe contractée par la mere pendant la grossesse est-elle nocive pour Гenfant ? 120

Rigillo, N.: vide Auricchio, S.

Rosenblith, J.F.: The Modified Graham Behavior Test for Neonates: Test-retest Relia bility, Normative Data, and Hypotheses for Future Work. - Le test de Graham (modifié) pour Vetude du comportement du nouveau-né: Validíté du test-retest, donnêes normatíves, et hypotheses relatives aux recherches futures. - Die Test-Retest-Zuverlässigkeit und Normal werte des modifizierten Graham-Verhaltenstests für Neugeborene mit Hypothesen für eine zukünftige Arbeit174

Salmi, T.; Hänninen, P. and Peltonen, T.: The Electrocardiograms of Premature Infants in the First Month of Life. II. Unipolar Chest and Limb Leads. - Electrocardíogramme du premature dans le premier mois de la vie. II. Derivations précordiales et des membres. - Das Elektrokardiogramm von Frühgeburten im ersten Lebensmonat. II. Unipolare Brustwand- und Extremitätenableitungen 275

Schwick, G.: vide Koch, P.

Stave, U. und Cara, J.: Adenosinphosphate im Blut Frühgeborener. -Adenosine Phosphates in the Blood of Prematures. - Adenosine phosphates dans le sang des prematures .... 160 
Stern, L.; Lind, J. and Kaplan, B.: Direct Human Foetal Electrocardiography (with Studies of the Effects of Adrenalin, Atropine, Clamping the Umbilical Cord, and Placental Separation on the Foetal ECG). - Electrocardiographie directe du foetus humain (avec

etude des effets sur Гélectrocardiogramme fcetal de Гadrénalíne, Vatropíne, le clampage du cordon ombilícal et la separation placentaíre). - Direkte Elektrokardiographie beim menschlichen Foetus (mit Untersuchungen über die Wirkungen von Adrenalin, Atropin, Abklemmung der Nabelschnur und plazentarer Trennung auf das foetale EKG) 49 Stone, Sh.M. : vide Cohlan. S. Q.

Swierczewski, E.; Gibelin, C. et Minkowski, A.: Glutathion dans les globules rouges de la veine ombilicale: Comparaison avec le glutation dans les globules rouges de la femme enceinte. - Glutathíone in the Red Cells of the Umbilical Vein: Comparison with Glutathione in the Red Cells of the Pregnant Woman. - Der Glutathiongehalt der roten Blutkörperchen von Nabelvenenblut im Vergleich zum Erythrozyten-Glutathiongehalt des Schwangerenblutes 321

Swierczewski, E.: vide Chanez-Bel, C.

Takeuchi, A. and Benirschke, K.: Renal Venous Thrombosis of the Newborn and its Rela tion to Maternal Diabetes. Report of 16 Cases. - Thrombose des veines rênales chez le nouveau-né et ses rapports avec un díabète maternel. Compte rendu de 16 cas. - Nierenvenenthrombose des Neugeborenen und ihre Beziehung zum mütterlichen Diabetes. Bericht über 16 Fälle $\quad 237$

Töndury, G.: vide Rickenbacher, J.

Wagner, H.: The Development to Full Functional Maturity of the Gastric Mucosa and the Kidneys in Fetus and Newborn. - La maturation fonctionnelle de la muqueuse gastrique et des reins chez le foetus et le nouveau-né. - Die Entwicklung bis zur vollen funktionellen Reife der Magenschleimhaut und der Nieren beim Fetus und Neugeborenen 257

Willenbockel, U.: Die Aktivität der alkalischen Organphosphatasen in der ersten Lebenszeit. - The Activity of Alkaline Organophosphatases in Early Life. - L'activité des organophosphatases alcalines au debut de la vie 289

Buchbesprechungen - Book reviews - Livres nouveaux 379

Varia 63,380

AПe Rechte, insbesondere das der Übersetzung in fretade Sprachen, vorbehalten, Ohne ausdrückliche Genehmigung des Verlages ist es auch nicht gestattet, dieses Buch oder Teile daraus auf photomechanischem Wege (Photokopie, Mikrokopie) zu vervielfältigen.

(C)

Copyright 1961 by S. Karge $\Gamma$ AG, Basel

Printed in Switzerland

Cliches: Aberegg-Sterner \& Cie., AG, Bern und Sterner \& Cie., AG, Basel

Drack: Lüdin AG, Liestal 